\title{
COASTAL REVETMENT DESIGN PROCESS IN THAILAND
}

\author{
CHERDVONG SAENGSUPAVANICH \\ Faculty of International Maritime Studies, Kasetsart University, Thailand
}

\begin{abstract}
This article presents a current procedure that Thailand is undertaking to design a coastal revetment. Had Sai Kaew beach, located in the south of Thailand, experienced severe erosion. Coastal protection structure was urgently required. The design process comprised many steps such as a bathymetric survey, sediment sampling, wave climate analysis, water level calculation, wave transformation, public participations, a consideration of appropriate type of revetment, and a detailed design which included revetment's components as well as architectural improvement. These procedures were summarized. Coastal engineers and managers around the world might apply this experience to suit their projects.

Keywords: coastal engineering and management, revetment, shore protection, Thailand.
\end{abstract}

\section{INTRODUCTION}

Coastal erosion is a problem in many countries [1]-[5]. Houses are drowned. Lands are swallowed by the sea. Infrastructures are collapsed. Coastal people are suffered from destructions induced by big waves. Wave overtopping damages public and private properties. In Thailand, coastal erosion occurs along most of the coastline [6]-[8]. Causes of the erosion include man-made activities as well as natural phenomena [9], [10]. In some locations, both causes occur simultaneously, increasing severity of the erosion. For example, down-drift erosion that is created by a gigantic coastal structure obstructing the alongshore sediment transport is intensified by high waves attacking the coast during monsoon seasons. If the erosion-prone area is near important locations such as towns or other culturally, socially, ecologically valuable places, coastal structures should be designed.

Songkla province is located in the south of Thailand (Fig. 1). It is a long stretch of sandy coastline. Main wave direction is eastward (Fig. 2). The calm period covers $66.03 \%$ of the year. Waves having wave height larger than $2 \mathrm{~m}$ occur during November to March. The 50-year-return-period offshore significant wave height $\left(\mathrm{H}_{0} \mathrm{~s}\right)$ is expected to be as big as 5.38 $\mathrm{m}$ with the wave period (T) of $12.58 \mathrm{~s}$. Along Had Sai Kaew shoreline, the waves damaged coastal structures and negatively affected coastal communities. Roads, houses, and other infrastructures were collapsed (Fig. 3). The government spent a lot of budget to repair the damaged structures. The shoreline has been severely eroded. The erosion magnitude was greater than $5 \mathrm{~m} /$ year. A coastal protection structure is urgently required. Ill-designed coastal protection structures may not function well and collapse in a short period of time. This article presents how Thailand currently designs a revetment for coastal protection.

A current approach that Thailand is undertaking to design the revetment involves many steps. The design process began with a gathering of field data, including bathymetry and topography, sediment characteristics, subsoil information, and existing coastal structures. In the meantime, a local wave characteristic was synthesized from wind data. Long-term wave prediction was then carried out. Two formal meetings were organized in order to involve local communities and other stakeholders. Their inputs were incorporated into the design of the revetment. These steps consumed time and resources, but were worthwhile because the coastal protection structure could effectively protect the coast as well as created other benefits to the local people. Lessons learnt from this article may provide useful guideline for similar cases around the world. 


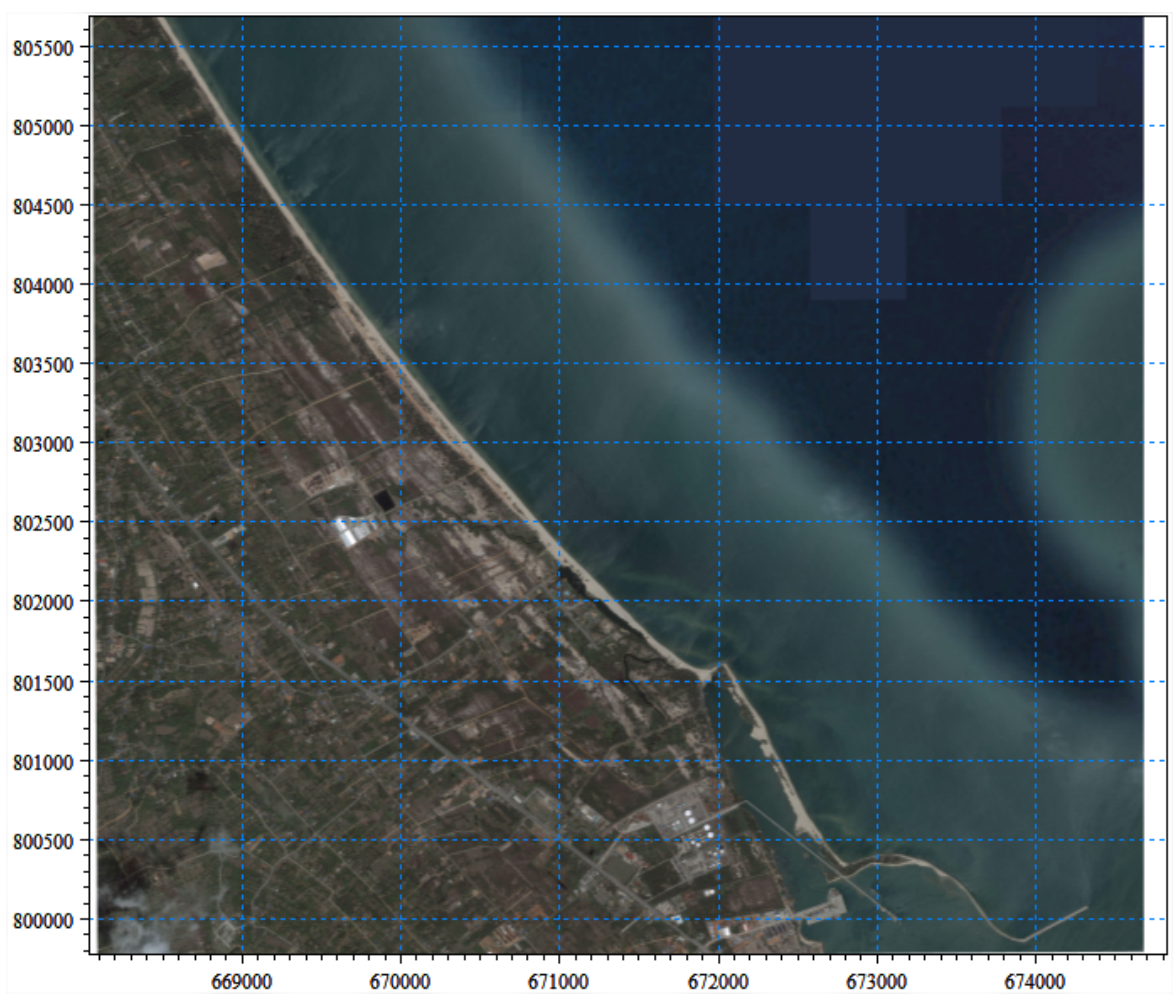

Figure 1: Study area.

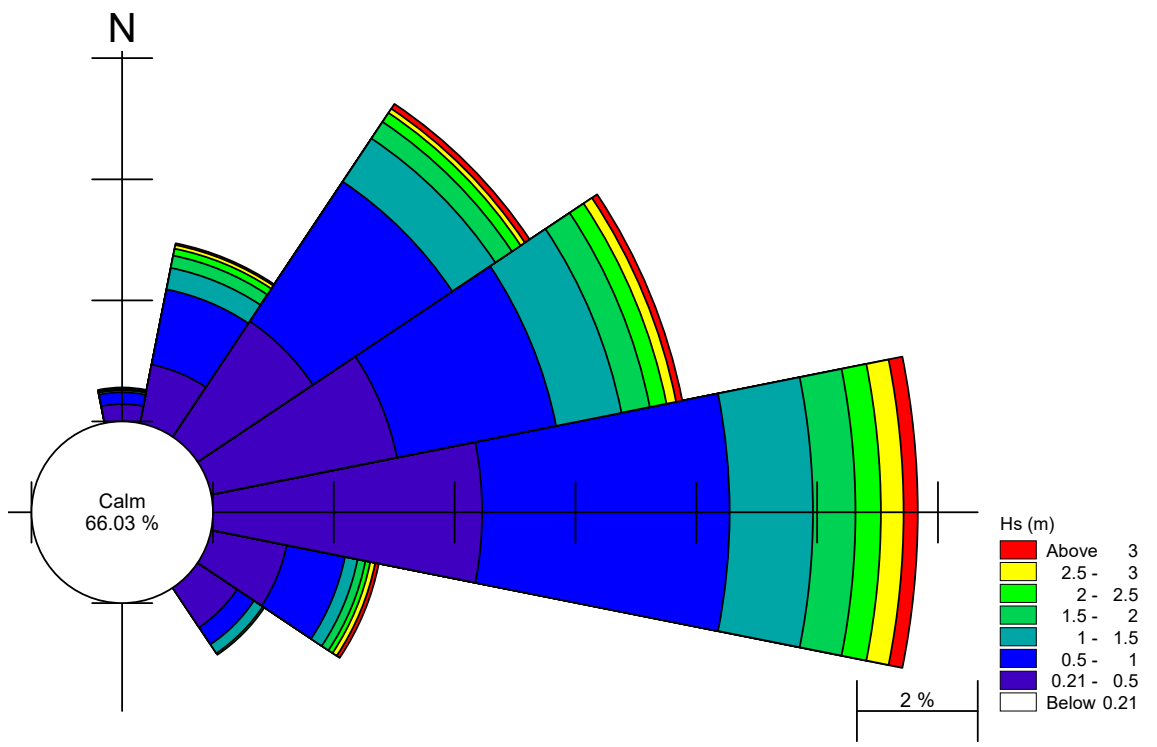

Figure 2: Annual wave rose. 

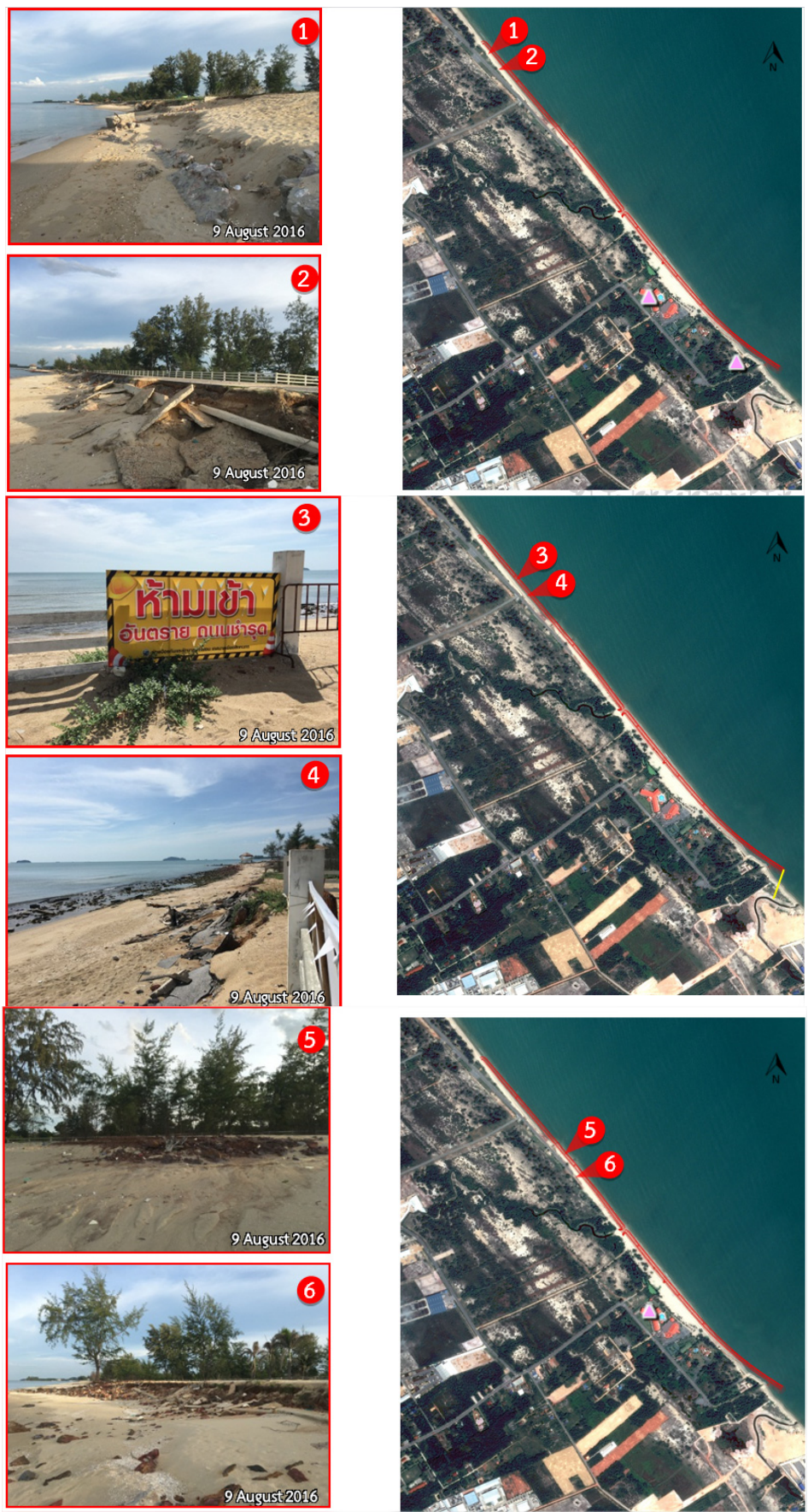

Figure 3: Severity of the erosion. 


\section{DATA COLLECTION AND ANALYSIS}

\subsection{Bathymetric survey}

A survey team gathered related field data. Echo sounding was utilized to produce a map. The bathymetric survey was undertaken with a $25-\mathrm{m}$ interval. The sounding extended approximately $2 \mathrm{~km}$ offshore. Cross-shore beach profiles were prepared. The collected field data was then synthesized to produce a map having grid size of $5 \times 5 \mathrm{~m}$, which in turn was used for computer simulation (Fig. 4). The map indicated that nearshore beach slope was steeper than offshore area.

\subsection{Sediment characteristic}

Beach sediment was collected and analyzed by sieve-hydrometer analysis. The sediment was categorized as find sand, having $\mathrm{D}_{50}$ of $0.22 \mathrm{~mm}$ (Fig 5). Sediment size and gradation affects amount of alongshore sediment transport.

\subsection{Water level}

Water level plays an important role in a design of revetment. Long-term water level statistics such as highest high water and mean high water spring was crucial for the design of revetment components such as crest elevation and revetment berm. The water level statistics was collected from the nearest tidal station (Table 1).

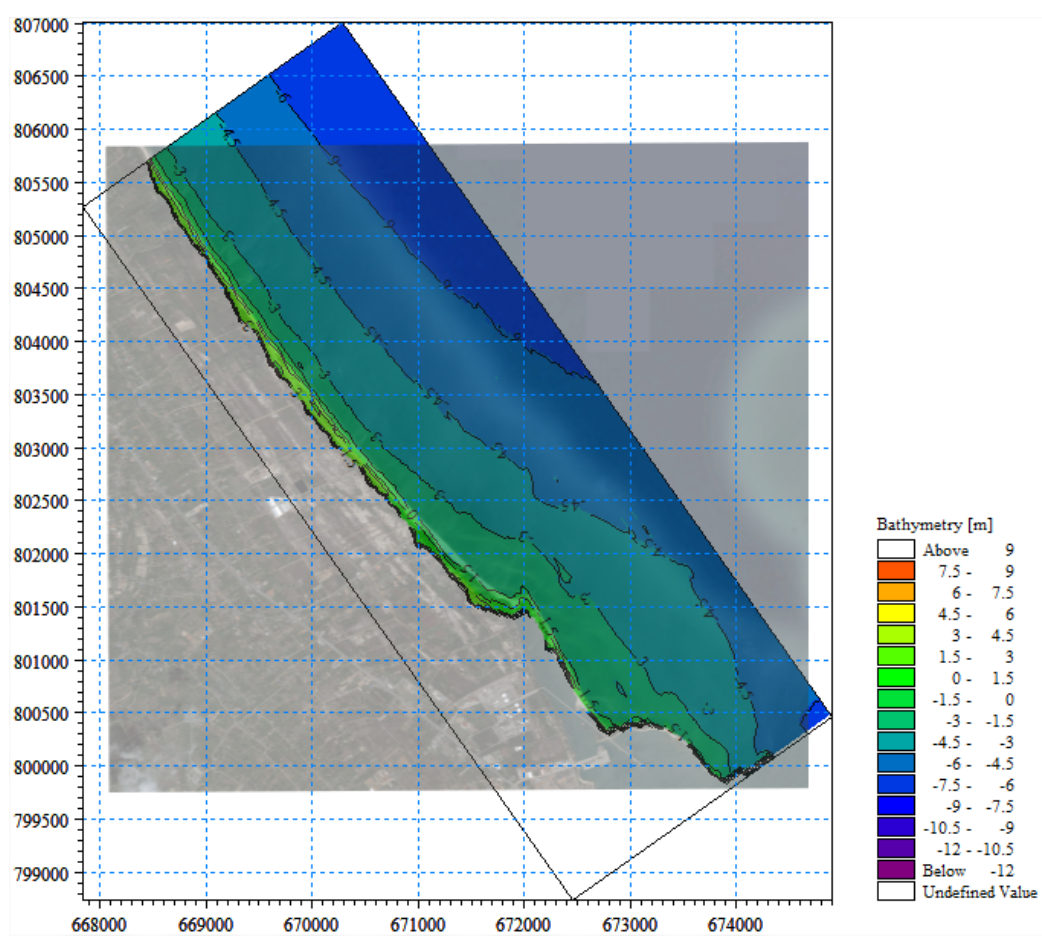

Figure 4: A bathymetry map. 


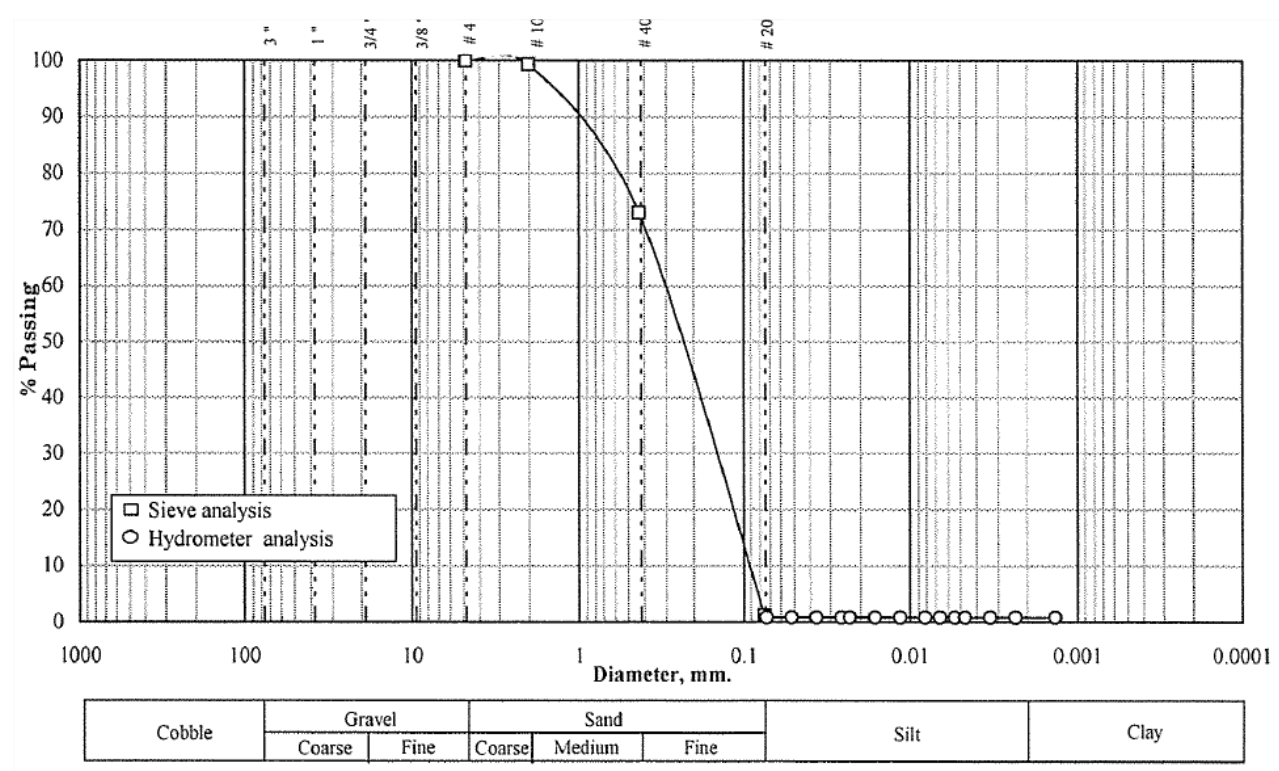

Figure 5: Sediment characteristics.

Table 1: Long-term tidal statistics.

\begin{tabular}{|l|l|}
\hline & Tidal elevation $(\mathrm{m} \mathrm{MSL})$ \\
\hline Highest high water (HHW) & +084 \\
\hline Mean high water spring (MHWS) & +0.01 \\
\hline Local mean sea level & -0.04 \\
\hline
\end{tabular}

Wind setup and wave setup were calculated by eqn (1) [11] and eqn (2) [12], respectively.

$$
\frac{d S}{d x}=\frac{\zeta(U \cos \theta)^{2}}{g D}
$$

where $S$ is the wind setup (m), $x$ is the distance $(\mathrm{m}), \zeta$ is a constant being $3.2 \times 10^{-6}, U$ is the design wind speed $(\mathrm{m} / \mathrm{s}), \theta$ is the angle that wind blows towards the shore, $g$ is gravitational acceleration $=9.81 \mathrm{~m}^{2} / \mathrm{s}$, and $D$ is the depth of a certain point adding the wind setup.

$$
\frac{\delta}{H_{0 s}}=A_{0}+A_{1} \ln \left(\frac{H_{0 s}}{L_{0}}\right)+A_{2}\left[\ln \left(\frac{H_{0 s}}{L_{0}}\right)\right]^{2}
$$

Where $\delta$ is wave setup at shoreline $(\mathrm{m}), H_{0 s}$ is offshore significant wave height $(\mathrm{m})$, $A_{0}=0.0063+0.768 s, A_{1}=-0.0083-0.011 s, A_{2}=0.00372+0.0148 s$, and $s$ is beach slope.

After the wind setup and wave setup were determined, the design water level was calculated. The MHWS was selected as a base water level. Adding all the setups with the MHWS, the design water level was achieved as $+1.02 \mathrm{~m}$ MSL. Finally, the depth in front of the revetment's toe was $1.52 \mathrm{~m}$ (Fig. 6). 


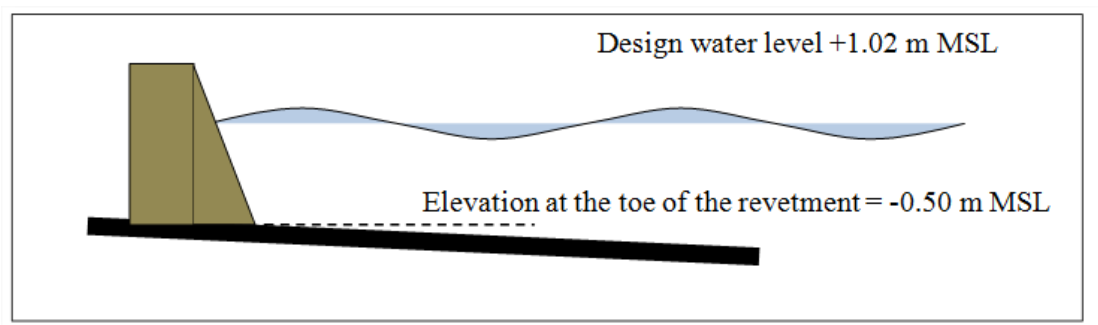

Figure 6: The design water depth in front of the revetment.

\subsection{Wave transformation}

Offshore waves cannot reach the shoreline without transforming. Waves undergo various processes such as refraction, shoaling, and breaking. The wave height at the toe of the structure is one of the most important parameters, since it pertains to calculation of rock size, crest width, wave run-up, wave overtopping, and scour protection. A software package called MIKE21 PMS was applied for nearshore wave transformation. It has been applied by many researchers and coastal practitioners to study wave propagation in the ocean [13], [14].

The simulation results suggested that offshore waves propagating into the shore would break. The 50-year-return-period offshore significant wave height $\left(\mathrm{H}_{0} \mathrm{~s}\right)$ would reduce to 0.86 $\mathrm{m}$ at the toe of the revetment (Fig. 7).

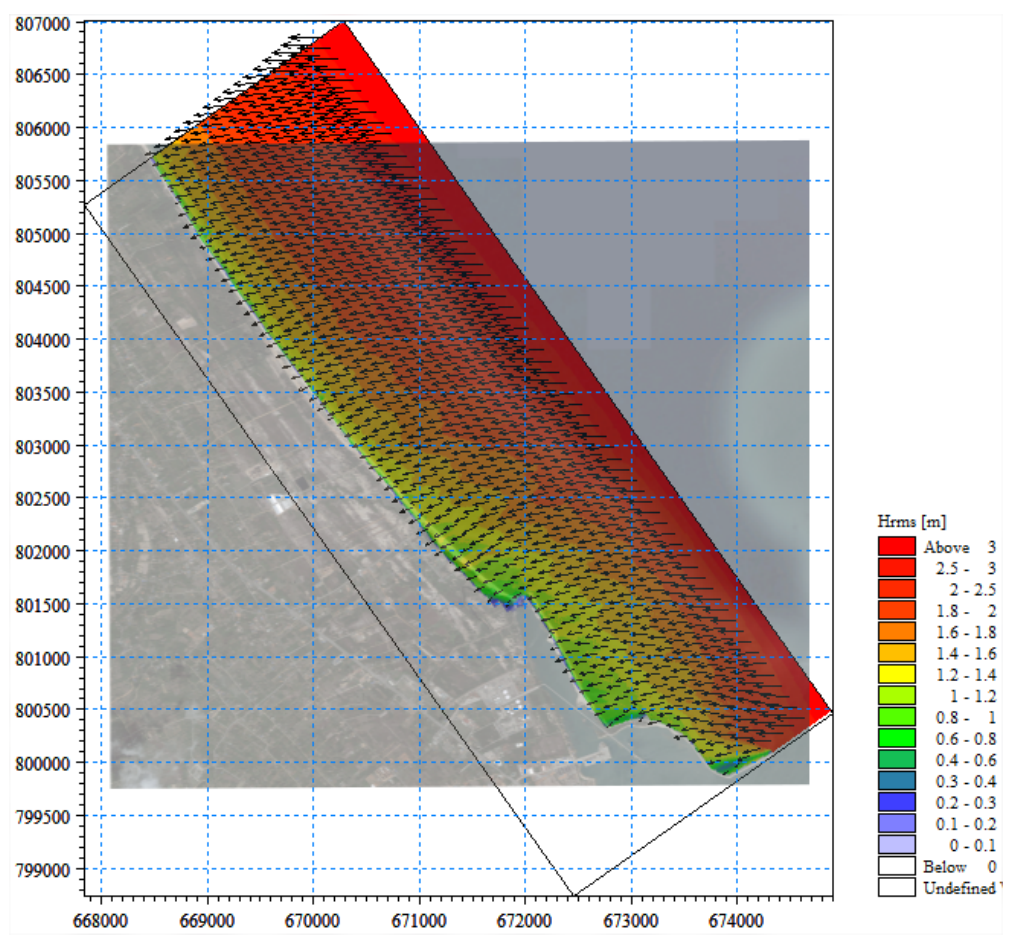

Figure 7: Wave height approaching the shoreline. 


\subsection{Public participation}

Stakeholder participation is indispensable for a successful coastal protection project. The coastal protection structure installed must support local way of life. Tourist beach and rural beach require different type of revetment. A revetment constructed in the urban area should be able to enhance tourism, although some annual revetment maintenance is required since revetment's crest elevation cannot be too high and crest width cannot be too wide. In contrast, the revetment designed for rural community where a local government does not have plenty of budgets for annual repair should require least maintenance. The rural revetment's priority is to protect coastal villages, while enhancing the tourism may not be important.

Designing coastal revetment in Thailand has evolved. In the past, a coastal engineer designed a revetment without involving coastal communities. Nowadays, the law dictates that every government's project must carry out public participations. For this study, two formal meetings were organized and many informal meetings with local leaders as well as local government representatives were undertaken. Personal interviews with households located within 1-km radius were carried out.

An objective of the first formal meeting was to introduce the coastal protection project to stakeholders (Fig. 8). In the first meeting, five types of revetment were presented to the participants (Fig. 9); rock revetment, gabion revetment; stepped concrete revetment, curvefaced concrete revetment, and concrete revetment with blocks. Their opinions were recorded and they could suggest other types of revetment. The meeting took approximately 3 hours. A lot of stakeholders such as conservationists, local government representatives from different departments, fishermen, hotel owners, and other interested persons expressed their supports and concerns. Environmental mitigation measures were presented. At the end of the meeting, the participants were asked to vote for the appropriate type of revetment that they consider suitable for Had Sai Kaew beach.
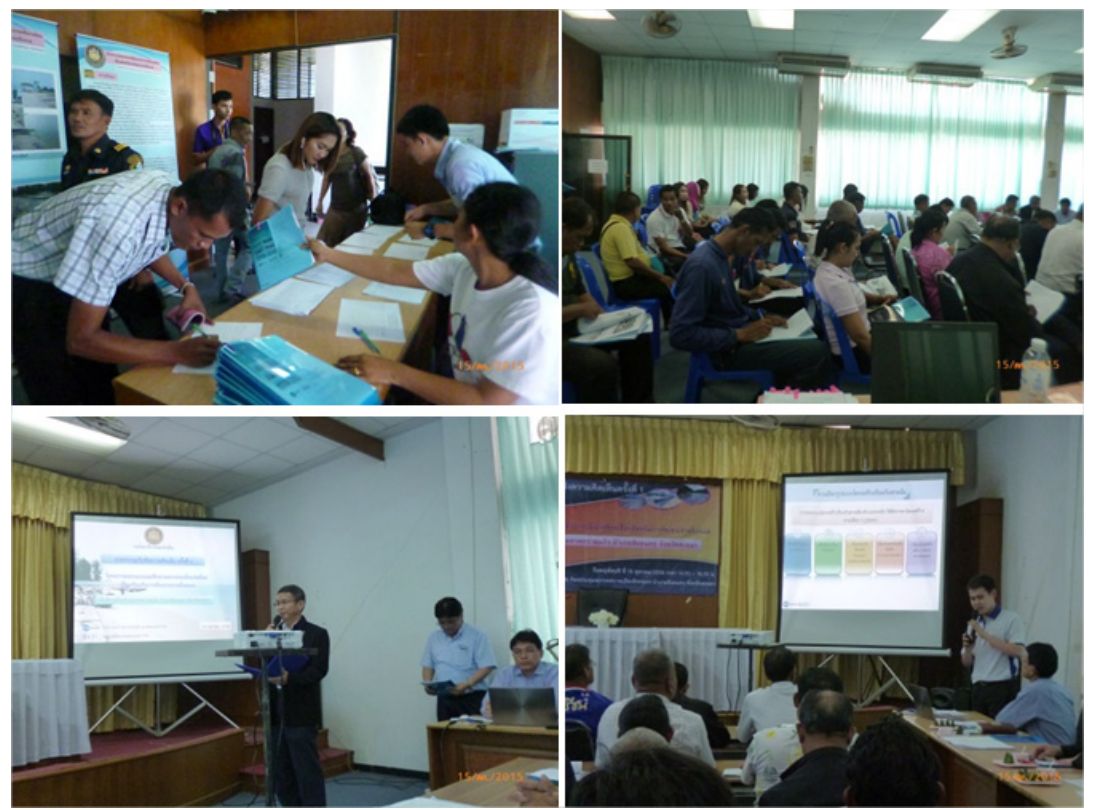

Figure 8: Public participation. 

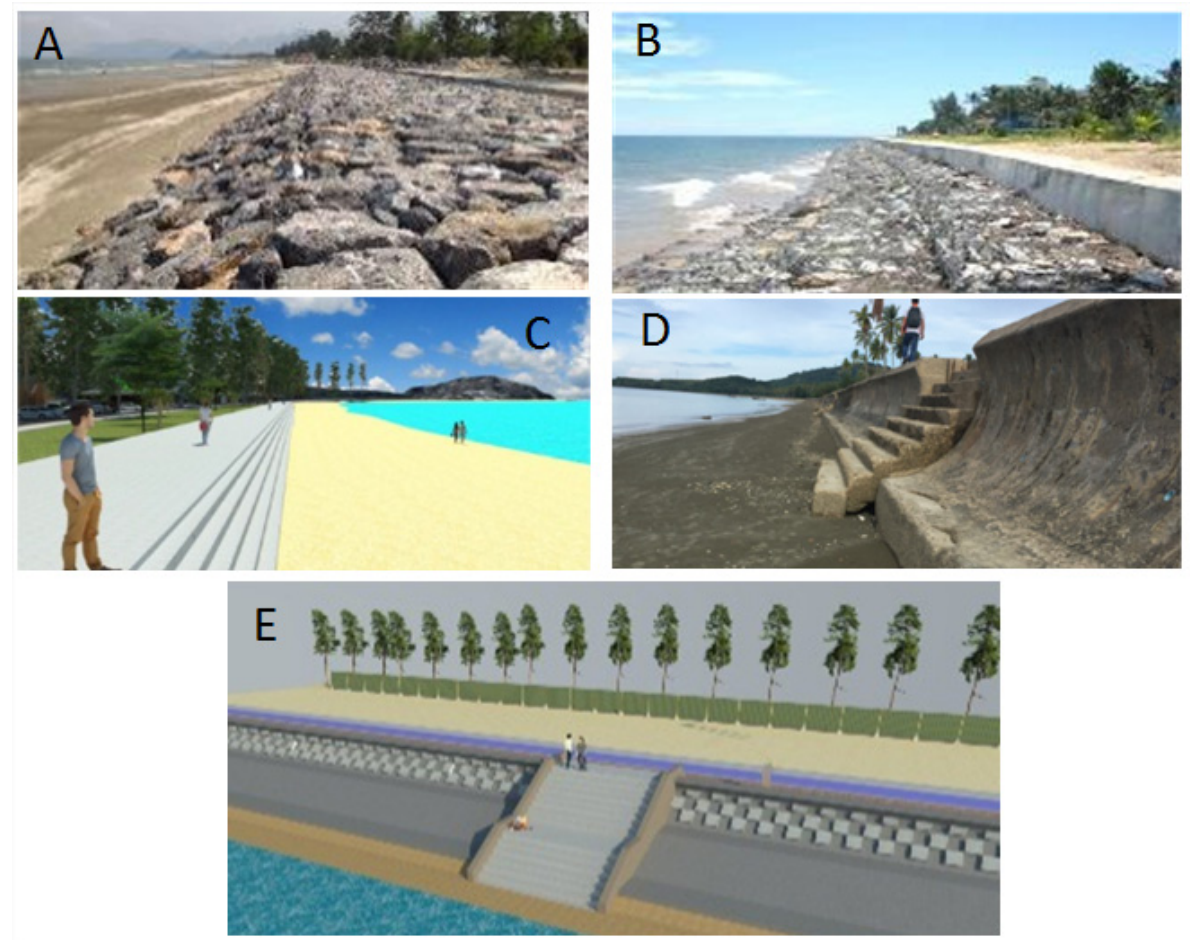

Figure 9: Types of revetment presented in the first formal meeting. A. rock revetment; B. gabion revetment; C. stepped concrete revetment; D. curve-faced concrete revetment; E. concrete revetment with blocked surface.

After acquiring opinions from the participants, a coastal engineer who was responsible for designing the revetment incorporated the suggestions into the design process. A team of environmentalists collected samples to analyze an existing environmental condition (Fig. 10). After the revetment design was completed, initial environmental evaluation (IEE) was undertaken. Environmental mitigation measures were stated so that when the revetment construction began, the construction activities would not severely affect the environment. Ten months later, the second formal meeting was organized. All results during the whole process were presented. The participants were urged to express their concerns or improvements on any aspect.

\section{THE REVETMENT DESIGN}

\subsection{Multi-criteria analysis}

Each type of revetment has different strengths and weaknesses. For example, a rock revetment is durable and can significantly reduce wave run-up but it may not be as beautiful as a concrete revetment. In contrast, the smooth-surfaced concrete revetment conforms to tourism beaches but suffers from a large quantity of wave overtopping. Construction costs also vary. For a selection procedure of the most appropriate type of revetment, eight criteria were established. Each criterion had its own weighting score (Table 2). 


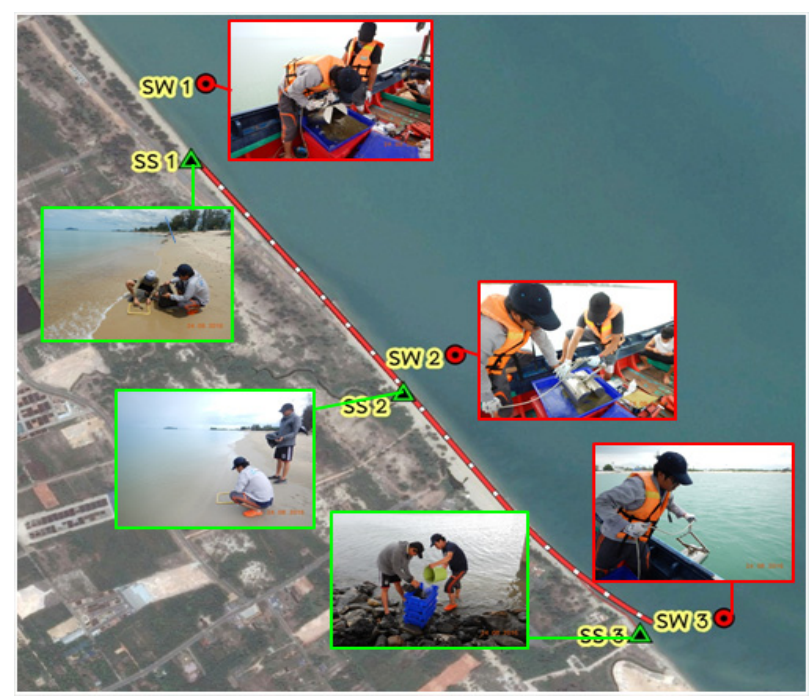

Figure 10: Environmental sampling.

Table 2: Criteria for revetment selection.

\begin{tabular}{|l|l|}
\hline Criteria & Weights (\%) \\
\hline Beach protection & 15.18 \\
\hline Constructability & 7.14 \\
\hline Maintenance & 10.71 \\
\hline Flexibility & 9.82 \\
\hline Accordance with society & 14.29 \\
\hline Environmental impacts & 16.07 \\
\hline Stakeholder acceptance & 18.75 \\
\hline Construction cost & 8.04 \\
\hline Total & 100 \\
\hline
\end{tabular}

- Beach protection: Structures must be able to protect shoreline from waves. The effective structures should also be able to limit wave overtopping.

- Constructability: Some structures are difficult to construct and involve a lot of construction processes. The ones that can be installed easily and fast are preferred.

- Maintenance: Structures that require less maintenance are better than the ones that must be continuously repaired.

- Flexibility: In a case when a structure fails, it should be able to slow down the erosion until the budget for the repairs arrives.

- Accordance with society: Coastal protection structures must not only protect the coast but also enhance local livelihood. Occupations of local inhabitants are one of the key factors.

- Environmental impacts: An appropriate coastal protection structure should negatively affect the environment as little as possible. 
- Stakeholder acceptance: In the questionnaire distributed during the first public meeting, the attendance was requested to vote for the structure considered appropriate. The most voted structure received the highest score.

- Construction cost: The cost of construction is a financial consideration.

After analyzing all criteria, the appropriate type of revetment to be constructed at Had Sai Kaew beach was the concrete revetment with blocked surface. The responsible coastal engineer then began to design the revetment in the following section.

\subsection{Design of the revetment}

The concrete revetment with blocked surface was carefully designed by an engineering team. The coastal engineer firstly designed major components of the revetment such as a crest high enough to limit wave overtopping, and a toe buried deep enough to prevent scouring. The revetment's berm width was optimized. A parapet was installed at the revetment's crest. Blocks were also designed to further reduce the overtopping. These processes were applied using various formula (Table 3 ) but the details were excluded from this article. Later, the geotechnical engineer assessed an overall stability of the revetment and designed pile foundations. Finally, the architect improved overall atmosphere to blend the revetment with environmental surrounding. Artistic impressions of the final revetment were presented in Fig. 11.

Table 3: Formula applied for the revetment design.

\begin{tabular}{|l|l|}
\hline Formula & References \\
\hline Overtopping discharge & Van der Meer [15] \\
\hline Parapet design & Doorslaer et al. [16] \\
\hline Crest protection & Pilarczyk [17] \\
\hline Toe protection & Mcconnell [18] \\
\hline Block surface design & Capel [19] \\
\hline
\end{tabular}
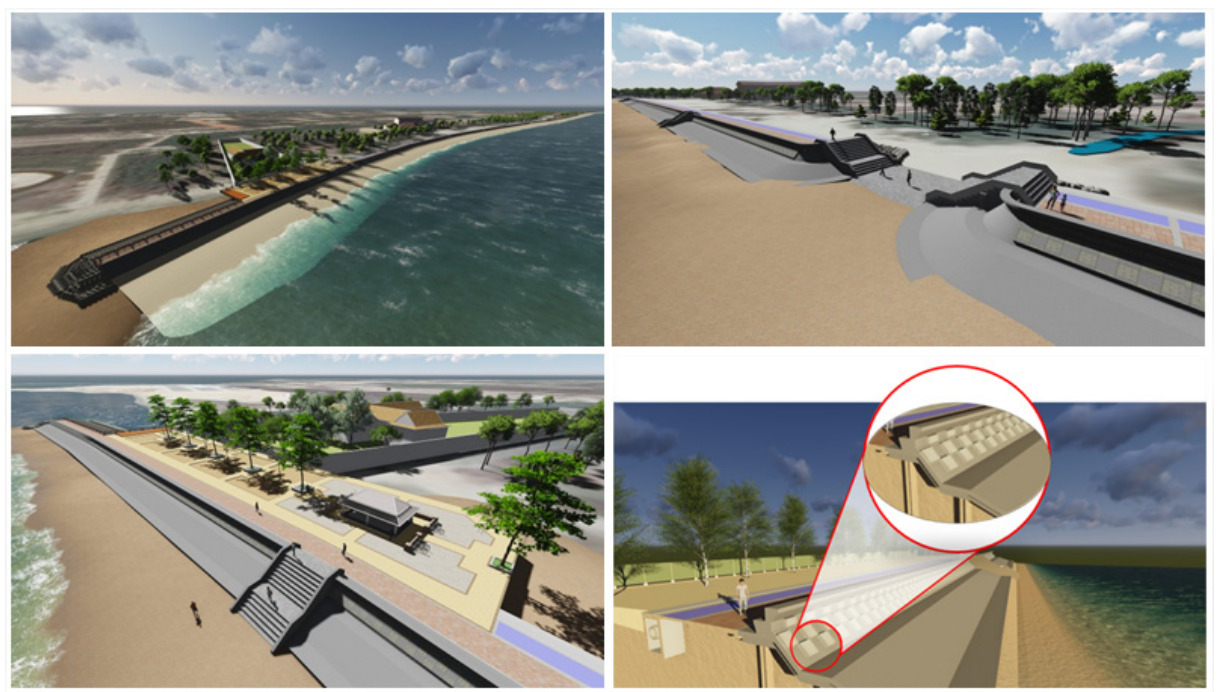

Figure 11: Artistic impressions of the revetment. 


\section{DISCUSSION AND CONCLUSION}

Designing a revetment is not an easy task as it involves numerous processes. Engineering, social, environmental, and financial aspects are intertwined and needed to be simultaneously considered. Each component has its own procedures, ranging from field data gathering to organizing public participation meetings. This article presents how Thailand is designing the revetment. It emphasizes on the overall process rather than engineering calculations. Although, the design process in Thailand may not be the best in the world, readers can understand and may use this case study to suit their particular situations.

\section{ACKNOWLEDGEMENTS}

The author would like to express his gratitude to Mr. Suwat Buayam for his kind support. I also thank STS Engineering Consultants Co. Ltd., Thailand, as well as MACRO Consultant Co. Ltd. Thailand for their valuable inputs.

\section{REFERENCES}

[1] Cao, W. \& Wong, M.H., Current status of coastal zone issues and management in China: a review. Environment International, 33, pp. 985-992, 2007.

[2] Cellone, F., Carol, E. \& Tosi, L., Coastal erosion and loss of wetlands in the middle Río de la Plata estuary (Argentina). Applied Geography, 76, pp. 37-48, 2016.

[3] Fitton, J.M., Hansom, J.D. \& Rennie, A.F., A national coastal erosion susceptibility model for Scotland. Ocean \& Coastal Management, 132, pp. 80-89, 2016.

[4] Houwing, E., Morphodynamic development of intertidal mudflats: consequences for the extension of the pioneer zone. Continental Shelf Research, 20(12-13), pp. 1735-1748, 2000.

[5] Lin, J., Coastal modification due to human influence in south-western Taiwan. Quaternary Science Reviews, 15, pp. 895-900, 1996.

[6] Saengsupavanich, C., Chonwattana, S. \& Naimsampao, T., Coastal erosion through integrated management: a case of Southern Thailand. Ocean \& Coastal Management, 52, pp. 307-316, 2009.

[7] Saengsupavanich, C., Assessing and mitigating impacts of shore revetment on neighboring coastline. 2012 International Conference on Environment Science and Engineering, Bangkok, Thailand, 2012.

[8] Saengsupavanich, C., Erosion protection options of a muddy coastline in Thailand: Stakeholders' shared responsibilities. Ocean \& Coastal Management, 83, pp. 81-90, 2013.

[9] Bird, E.C.F., Coastal Geomorphology: An Introduction, $2^{\text {nd }}$ ed., John Wiley \& Sons: UK, 2008.

[10] Cicin-Sain, B. \& Knecht, R.W., Integrated Coastal and Ocean Management: Concepts and Practices, Island Press: USA, 1998.

[11] Kamphuis, J.W., Introduction to Coastal Engineering and Management. Advanced Series on Ocean Engineering, Vol. 16, World Scientific: Singapore, 2000.

[12] Goda, Y., Wave setup and longshore current induced by directional spectral waves: Prediction formulas based on numerical computation results. Coastal Engineering Journal, 50(4), pp. 397-440, 2008.

[13] Simeoni, U., Corbau, C. \& Letizia, P., Evolution of geminations along the Goro Spit: First results. Journal of Coastal Research, 56, pp. 123-127, 2009.

[14] Sloth, P., Fuchs, J., Kofoed-Hansen, H., Mortensen, S.B. \& Mühlestein, D., Wave transformation and overtopping challenges solved by multi-disciplinary modelling, 8 th 
44 Coastal Cities and their Sustainable Future II

International Conference on Coastal and Port Engineering in Developing Countries, Chennai, India, 2012.

[15] Van de Meer, J.W., Wave run-up and overtopping. In: Pilarczyk, K.W. (ed.), Dikes and Revetments, A.A. Balkema: Rotterdam, pp. 145-159, 1998.

[16] Doorslaer, K.V., Rouck, J.D., Audenaert, S. \& Duquet, V., Crest modifications to reduce wave overtopping of non-breaking waves over a smooth dike slope. Coastal Engineering, 105, pp. 69-88, 2015.

[17] Pilarczyk, K.W., Dikes and Revetments: Design, Maintenance, and Safety Assessment, A.A. Balkema: Rotterdam, 1998.

[18] Mcconnell, K., Revetment Systems Against Wave Attack - A Design Manual, Redwood Books: Great Britain, 1998.

[19] Capel, A., Wave run-up and overtopping reduction by block revetments with enhanced roughness. Coastal Engineering, 104, pp. 76-92, 2015. 